\title{
The Role of New Media in Building Social Skills of Students with and without Disabilities
}

\author{
Eva Brlek \\ University North, Koprivnica, Croatia \\ evbrlek@unin.hr \\ Ljerka Luić \\ University North, Koprivnica, Croatia \\ ljluic@unin.hr \\ Jelena Škoda \\ University North, Koprivnica, Croatia \\ jeskoda@unin.hr
}

\begin{abstract}
Summary
Digital technologies are an integral part of our everyday life, and new media have changed the way we communicate. New forms of communication are most evident among school children, whose upbringing and education is marked by the immersion in the world of social media and internet technologies. The authors of this paper aim to analyze the influence of new media on the development of school children's social skills. It is based on a quantitative study of the impact of the length of daily usage of new media on elementary school students' social skills (with and without disabilities), seen from the perspective of both parents and teachers. The results were gained by the survey conducted on a representative sample of primary schools in the Republic of Croatia in the school year 2018/2019. Comparative analysis of the results obtained with similar research results led to a conclusion of the synergistic impact of new media and new communication channels on the development of social skills of students. The authenticity of this research is established in the approach involving both parents and teachers and the material on which the research was conducted (students with and without disabilities). The scientific contribution was achieved at different levels: at the cognitive level through the development of information concepts of social skills, while at the methodological level through the development of original methodology of qualitative comparison of respondents' attitudes by making a statistical analysis of dynamic ontological parameters. Finally, on the practical level through the application of defined information concepts in the study of the impact of new media on the development of social skills.
\end{abstract}

Key words: new media, new communication channels, social skills, students with and without disabilities

\section{Introduction}

The upbringing and education of children and young people for modern life in the 21st century is directed towards gaining competences that are essentially different from those prevailing in the past. The question that arises in the broader social context, enriched with modern information and communication technologies, is how much and to what extent are social skills of children affected by new media. The term new media most commonly refers to internet content, computer multimedia, video games, and virtual reality. But the definition of the term new media is more complex than it seems. Lievrouw and Livingstone (2006: 2) define new media as 'Information and communication technologies and their social contexts with three key components: devices used to communicate or transmit information; activities and practices in which people engage in communication and social patterns that develop by using these devices and practices." The adjective "new" in the name itself, implies a dichotomy with respect to some "old" media. Analyzing a wide range of changes in media production, distribution, and use, Lister et al. (2009: 13) consider changes in media from a 
technological, textual, conventional, and cultural point of view, and find that the media we define as new are "digital, interactive, hypertextual, virtual, networked and simulated." Because of these characteristics, the media is an extremely important socializing agent in today's world. Socialization is broadly defined as "the process during which people acquire attitudes and values of a particular culture and learn behaviors that are considered appropriate for individuals as members of a particular society" (Raboteg-Šarić, 1997: 423). The most important immediate agents in the primary socialization process of children and young people are parents, siblings, peer groups, pre-schools and educational institutions.

Table 1. Social skills

\begin{tabular}{|c|c|}
\hline Basic social skills & Secondary social skills \\
\hline Listening & Seeking help \\
\hline Starting a conversation & Asking for information \\
\hline Holding a conversation & Giving directions \\
\hline Asking questions & Following directions \\
\hline Ending a conversation & Providing assurance \\
\hline Introducing oneself & Apologizing \\
\hline Introducing others & Self-control \\
\hline
\end{tabular}

Adapted from Rajić, A., (2011.), http://oc-pgz.hr/clanci_socijalne_vjestine.html

Developed social skills of an individual are the foundation of all relationships and one of the best predictors of healthy functioning in adulthood. In order for a child to maintain good face-to-face relationships with peers and adults, he or she must master basic social skills like listening, holding a conversation, seeking help or playing a game (Miljković, Rijavec, 2002). Children with welldeveloped social competences, have high self-esteem and self-respect; feel supported and loved by their peers, parents and other adults; they feel included and wanted rather than isolated; they are surrounded by many people who they can spend time with; they are involved in large, organized social groups such as sports clubs, religious groups, classes; they have people in their life who they can share their experiences with, their thoughts and feelings. Generally, they have a positive outlook on life and are open-minded so other people want to be around them (Klarin, 2006). Previous research of the role of new media in the understanding of social learning theory is extremely important, since the likelihood of remembering and assuming a particular rule or model of behavior depends on the strength and complexity of the internalized pattern, which is mainly conditioned by the attractiveness of the observed content (Livazović, 2009: 110). Zgrabljić Rotar (2005: 8) states that children are not only influenced by what is received through the media, but also by the passivity of the environment in which children grow up, that is, the passive family and school, which results in their personal passivity and the absence of emotional and intellectual readiness for life with the media. Ilišin (2001: 176) considers that the media are becoming the main element of socialization, therefore they surpass school, family life, etc. and thus influence the overall formation of values and behaviors of young people. It is possible to distinguish the risk and protective factors, as well as the short- and long-term factors of the influence of new media on the development children and young people's skills. Alexander and Hanson (2003) find that they threaten to form a lasting system of beliefs, attitudes and habits as a daily pattern of living and behavior in social interactions.

\section{Methodology \\ Objectives and hypotheses}

The aim of the conducted research on the basis of this paper was to explain the impact of new media on social skills of elementary school students, with or without disabilities, aged 7-14 years in the Republic of Croatia. At the same time, the objective was to determine the time and content dimension of media exposure and use, as well as which devices students prefer to use for media content. Also, the objective was to analyze and determine if there was a difference in the perception of social skills development between a teacher and a parent of an individual student. In accordance with the objectives, hypotheses were stated:

H1: Time spent on new media has a significant impact on the development of social skills in children with and without disabilities. 
$\mathrm{H} 2$ : There is a correlation between time spent using new media and parental control.

H3: There is no difference in the perception of social skills development between a teacher and a parent.

\section{Sample}

The sample of research participants consists of parents and teachers of 200 students of primary schools and 46 students of education centers from six counties in the Republic of Croatia. Children with disabilities included in the study have been diagnosed with autism spectrum disorder and attend special education programs. For each individual student, the parent and teacher answered the same questions on the survey questionnaire and their answers were processed and compared afterwards.

Parents $(\mathrm{N}=266)$ and teachers $(\mathrm{N}=266)$ answered questions about the habits of using new media of their child/student and assessed the basic social skills of their child/student on variables adapted from Rajić (2011). Only face-to-face interaction was taken into account when assessing the child/student's social skills while family and educational setting were chosen because they are the agents of primary socialization. The parents completed the questionnaire at the parent meeting while the teachers filled it out at school, in the class, and since they could not estimate themselves how much time each student spent using new media, they asked the students themselves and based on that provided an answer. We hypothesized that parents of underage students could fairly accurately state how much time their child spends using new media.

All grades of primary school are included, with age 10, being the average age of students $(\mathrm{M}=10.58)$. The majority of students are 13 years old, $61(22.9 \%)$, one student is 15 years old $(0.4 \%)$ and one is 18 years old $(0.4 \%)$ as they are students of Education Centre for children with disabilities who are being educated until they are 21 years old. A total number of teachers $(\mathrm{N}=266)$ and parents $(\mathrm{N}=266)$ of 220 students $(82.7 \%)$ without disabilities and $46(17.3 \%)$ students with disabilities participated in the survey where 123 were girls (50.4\%), and 132 boys (49.6\%). The difference between the sizes of the two groups of participants stems from the lower percentage of students with disabilities in general population.

\section{Results}

\section{Media time exposure and the use of devices}

Survey results related to the time and content dimension of media exposure and use showed that, on average, respondents spend 2 hours $(\mathrm{M}=2.01)$ daily with new media. The answers show that most children $53.7 \%$ spend 1 to 2 hours a day with new media, 25.2\% spend less than 1 hour, while $19.9 \%$ spend 3 hours or more using media. To determine whether there was a statistically significant difference in media use between children with and without developmental disabilities, a nonparametric Mann-Whitney test was selected because previous Q-Q plots analysis in the SPSS Statistical Data Processing Program determined that the data were not normally distributed. It was found that there was no statistically significant difference in time spent on new media between students with or without disabilities (Table 2). Also, both groups of respondents spend, on average, between one and two hours of watching television and playing video games. As can be seen from Table 1, The Mann-Whitney shows no statistically significant difference between the groups was found $(p>0.05)$.

Table 2. Total time spent with media daily

\begin{tabular}{|l|l|l|l|l|l|c|}
\hline \multirow{2}{*}{ Variable } & \multicolumn{2}{|l|}{ Mean rank } & \multicolumn{2}{l|}{ Summ of ranks } & $\begin{array}{l}\text { Mann } \\
\text { Whitney }\end{array}$ & $\mathrm{p}$ \\
\cline { 2 - 7 } & $\begin{array}{l}\text { Regular } \\
\text { development }\end{array}$ & Disabilities & $\begin{array}{l}\text { Regular } \\
\text { development }\end{array}$ & Disabilities & & \\
\hline $\begin{array}{l}\text { Total time spent } \\
\text { with media daily }\end{array}$ & 133,42 & 133,87 & 29353,00 & 6158,00 & 5043,00 & .969 \\
\hline $\begin{array}{l}\text { Total time spent } \\
\text { watching TV daily }\end{array}$ & 132,57 & 137,96 & 29165,00 & 6346,00 & 4855,00 & .632 \\
\hline $\begin{array}{l}\text { Total time spent } \\
\text { playing videogames }\end{array}$ & 136,53 & 118,99 & 30037,50 & 5473,50 & 4395,50 & .110 \\
\hline
\end{tabular}

Note: $* \mathrm{p}<.05, * * \mathrm{p}<.01, * * * \mathrm{p}<.001 ; \mathrm{N}=266$ (Regular development=220, Disabilities=46) 
The number of hours spent playing video games increases with the students' age, and 13-year-olds, are the age group included in the research that spends the most time playing videogames, then using the highest number of technological devices, they also watch television the most and spend the highest total number of hours with new media. The largest number of students, 103 (38.72\%), prefer using cell phones and laptops, the number of devices used by students is increasing according to the age of the students. Students with disabilities prefer to use a cellphone, while students of a regular development a cellphone and a laptop. In addition to the devices offered in the survey: a cellphone, a computer, Wii and Xbox, 4 parents indicated that children were using Play Station 4 while 1 parent indicated that the child was also using Play Station 3.

\section{Media content control}

It can be seen that there is no difference between the parents of a child with disabilities $(M=1.154$, $\mathrm{SD}=0.51792)$ and regular development $(\mathrm{M}=1.1739, \mathrm{SD}=0.38322)$ in controlling media content. As many as $88.35 \%$ of the parents of the respondents control the content that the children use. Although a smaller percentage of parents do not control media content, students without control spend more time with new media, television and video games (Table 3).

Table 3. Media content control

\begin{tabular}{|l|l|l|l|l|l|l|}
\hline \multirow{2}{*}{ Variable } & \multicolumn{2}{l|}{ Mean rank } & \multicolumn{2}{l|}{ Summ of ranks } & Mann Whitney & $\mathrm{p}$ \\
\cline { 2 - 7 } & Control & No control & Control & No control & & \\
\hline Total time & 126,09 & 174,97 & 29379,00 & 5074,00 & 2118,00 & $.000 * * *$ \\
\hline
\end{tabular}

Note: $* \mathrm{p}<.05, * * \mathrm{p}<.01, * * * \mathrm{p}<.001 ; \mathrm{N}=266$ (Media content control=235, The lack of media content control=31)

\section{The assessment of social skills by parents and teachers}

A Mann-Whitney nonparametric test was conducted to compare the assessment of the social skills of students with regular development and disabilities by parents, because the analysis found that the data in the variables did not correspond to the normal distribution. The differences were not determined on the following variables: the child waves and greets other people, the child accepts that he did not win the game. Significant differences were found in the variables: the child politely says no, makes eye contact when talking to other people, and has a difficult time making new friends.

Children of regular development stand up for themselves more commonly as they say no to others more often or ask someone to stop doing something that bothers them than the children with disabilities. Also, children of regular development make better eye contact while talking to others, and make new friends more easily.

Table 4. The assessment of social skills by parents

\begin{tabular}{|l|l|l|l|l|l|l|}
\hline \multirow{2}{*}{ Variable } & \multicolumn{2}{|l|}{ Mean rank } & \multicolumn{2}{l|}{ Summ of ranks } & $\begin{array}{l}\text { Mann } \\
\text { Whitney }\end{array}$ & $\mathrm{p}$ \\
\cline { 2 - 7 } & $\begin{array}{l}\text { Regular } \\
\text { development }\end{array}$ & Disabilities & $\begin{array}{l}\text { Regular } \\
\text { development }\end{array}$ & Disabilities & & \\
\hline Student greets & 135,47 & 124,07 & 29804,00 & 5707,00 & 4626,00 &, 333 \\
\hline Student says no & 143,15 & 87,37 & 31492,00 & 4019,00 & 2938,00 &, $000^{* * *}$ \\
\hline $\begin{array}{l}\text { Student makes eye } \\
\text { contact with people }\end{array}$ & 144,48 & 80,97 & 31786,50 & 3724,50 & 2643,50 &, $000^{* * *}$ \\
\hline $\begin{array}{l}\text { Student makes } \\
\text { friends }\end{array}$ & 123,99 & 187,97 & 27278,50 & 8232,50 & 2968,50 &, $000^{* * *}$ \\
\hline $\begin{array}{l}\text { Students accepts not } \\
\text { winning in a game }\end{array}$ & 133,73 & 132,42 & 29419,50 & 6091,50 & 5010,50 &, 913 \\
\hline
\end{tabular}

Note: $* \mathrm{p}<.05, * * \mathrm{p}<.01, * * * \mathrm{p}<.001 ; \mathrm{N}=266$ (Regular development=220, Disabilities=46)

A nonparametric Mann-Whitney test was conducted to compare the assessment of students' social skills of regular development and with disabilities by teachers. No differences were found on the following variable: the child accepts that he did not win the game. Significant differences were found in the variables: the student politely says no, makes eye contact when talking, and has difficulty making new friends. A slightly smaller but statistically significant difference is also evident in the variable child waving to others and greeting them. 
Children of regular development stand up for themselves more commonly as they say no to others more often or ask someone to stop doing something that bothers them than the children with disabilities. Also, children with regular development make better eye contact while talking to others, and make new friends more easily as it was shown by the parents' assessment as well.

Table 5. The assessment of social skills by teachers

\begin{tabular}{|l|l|l|l|l|l|l|}
\hline \multirow{2}{*}{ Variable } & \multicolumn{2}{|l|}{ Mean rank } & \multicolumn{2}{l|}{ Summ of ranks } & $\begin{array}{l}\text { Mann } \\
\text { Whitney }\end{array}$ & $\mathrm{p}$ \\
\cline { 2 - 7 } & $\begin{array}{l}\text { Regular } \\
\text { development }\end{array}$ & Disabilities & $\begin{array}{l}\text { Regular } \\
\text { development }\end{array}$ & Disabilities & & \\
\hline $\begin{array}{l}\text { Student greets other } \\
\text { people }\end{array}$ & 137,63 & 113,73 & 30279,50 & 5231,50 & 4150,00 &, $048 *$ \\
\hline Student says no & 145,55 & 75,85 & 32022,00 & 3489,00 & 2408,00 &, $000^{* * *}$ \\
\hline $\begin{array}{l}\text { Student makes eye } \\
\text { contact with people }\end{array}$ & 142,32 & 91,34 & 31309,50 & 4201,50 & 3120,50 &, $000 * * *$ \\
\hline $\begin{array}{l}\text { Student makes } \\
\text { friends }\end{array}$ & 128,24 & 158,64 & 28213,50 & 7297,50 & 3903,50 &, $000^{* * *}$ \\
\hline $\begin{array}{l}\text { Students accepts not } \\
\text { winning in a game }\end{array}$ & 130,79 & 146,47 & 28773,50 & 6737,50 & 4463,50 &, 190 \\
\hline
\end{tabular}

Note: $* \mathrm{p}<.05, * * \mathrm{p}<.01, * * * \mathrm{p}<.001 ; \mathrm{N}=266$ (Regular development=220, Disabilities=46)

There are almost no differences in assessments between parents and teachers in the field of social skills. The only difference is seen in the waving, greeting, and healing variables, where parents rated their children more positively than did the teachers.

\section{The correlation between hours spent with new media and social skills}

To determine whether there is a correlation between total time spent with new media and parents' assessment of social skills, we used Spearman's correlation coefficient. The results showed that, according to parents, there is a significant correlation between hours spent on new media and social skills (Table 6). There is a statistically significant association with hours spent on new media and students making eye contact with other people. Students who spend more than 1 hour with new media rarely make eye contact when talking, and find it difficult to make new friends.

Table 6 . The correlation between total time spent with new media and parents' assessment of variables

\begin{tabular}{|l|l|l|l|l|l|}
\hline & $\begin{array}{l}\text { Student greets } \\
\text { other people }\end{array}$ & $\begin{array}{l}\text { Student } \\
\text { Says no }\end{array}$ & $\begin{array}{l}\text { Student } \\
\text { makes eye } \\
\text { contact } \\
\text { with people }\end{array}$ & $\begin{array}{l}\text { Student } \\
\text { makes } \\
\text { friends }\end{array}$ & $\begin{array}{l}\text { Students } \\
\text { accepts not } \\
\text { winning in } \\
\text { a game }\end{array}$ \\
\hline $\begin{array}{l}\text { Student greets other } \\
\text { people }\end{array}$ & - &, $003 * *$ & $.001 * * *$ &, 389 &, 747 \\
\hline Student says no &, $003 * *$ & - &, $000^{* * *}$ &, $013 *$ & .306 \\
\hline $\begin{array}{l}\text { Student makes eye } \\
\text { contact with people }\end{array}$ &, $001 * * *$ &, $000^{* * * *}$ & - &, $000^{* * *}$ &, 084 \\
\hline Student makes friends &, 393 &, $014 *$ &, $000 * * *$ & - &, 301 \\
\hline $\begin{array}{l}\text { Students accepts not } \\
\text { winning in a game }\end{array}$ &, 725 &, 338 &, 106 &, 284 & \\
\hline
\end{tabular}

Note: $* \mathrm{p}<.05, * * \mathrm{p}<.01, * * * \mathrm{p}<.001$

Table 7. The correlation between total time spent with new media and teachers' assessment on variables

\begin{tabular}{|l|l|l|l|l|l|}
\hline Variable & $\begin{array}{l}\text { Student } \\
\text { greets } \\
\text { other people }\end{array}$ & $\begin{array}{l}\text { Student } \\
\text { says no }\end{array}$ & $\begin{array}{l}\text { Student makes } \\
\text { eye contact } \\
\text { with people }\end{array}$ & $\begin{array}{l}\text { Student } \\
\text { makes } \\
\text { friends }\end{array}$ & $\begin{array}{l}\text { Students accepts } \\
\text { not winning in a } \\
\text { game }\end{array}$ \\
\hline $\begin{array}{l}\text { Student greets other } \\
\text { people }\end{array}$ & - &, 980 & .190 &, 061 &, 613 \\
\hline Student says no &, 980 & - &, $000 * * *$ &, 115 & $.000 * * *$ \\
\hline Student makes eye &, 190 &, $000 * * *$ & - &, $000 * * *$ &, $001 * * *$ \\
\hline
\end{tabular}


E. Brlek, Lj. Luić, J. Škoda. The Role of New Media in Building...

\begin{tabular}{|l|l|l|l|l|l|}
\hline contact with people & & & & & \\
\hline Student makes friends &, 061 &, 115 &, $000 * * *$ & - &, $002 * *$ \\
\hline $\begin{array}{l}\text { Students accepts not } \\
\text { winning in a game }\end{array}$ &, 613 &, $000 * * *$ &, $001 * * *$ &, $002 * *$ & \\
\hline
\end{tabular}

Note: $* \mathrm{p}<.05, * * \mathrm{p}<.01, * * * \mathrm{p}<.001$

Spearman's correlation coefficient was used to determine whether there is a correlation between the variables: the total time spent with new media and the teachers' assessment of students' social skills (Table 7). The results show that, according to the teachers' assessment, there is a significant correlation between the hours spent on new media and the adoption of social skills. There is a statistically significant correlation between hours spent with new media as it making eye contact with other people is more difficult for students, they also tend not to stick up for themselves and do not say no to others when they disagree. Teachers also believe that students who spend more time using new media find it more difficult to make friends and become more involved in playing with other students.

\section{Discussion}

Changes in the media landscape are caused not only by the development of new media, but also by the transformation of traditional media (Valkenburg, Taylor Piotrowski, 2017: 2). Our research shows that, on average, students watch television for 1 to 2 hours a day, as much time as they spend on average playing video games daily mostly on smartphones or tablets because of touch sensitive technology that affects the way children are engaged in a play. Playing games is a very important source of learning social patterns and skills in elementary school, such as: acceptance in the environment, waiting for a turn, making friendships, conflict resolution skills (Katz, McClellan, 1999: 19), it is a very important factor in building social skills in children. The research conducted confirmed the hypothesis (H1) that time spent on new media significantly influences the adoption of social skills in children of regular development and children with disabilities. The results of the study show that students who spend more time using new media are less likely to express social patterns such as making eye contact with others, indicating that video games cannot replace the game through personal contact that encourages communication. Considering the role of the media, Ilishin (2003: 15) points out that children who are less satisfied with life and less socially adjusted are more likely to use the media, therefore the media can be understood as a compensation for real life deficiencies. The media do their real task only when they encourage learning, developing talent, good behavior, and emphasizing positive values in children (Rožić, 2015: 153).

Media education is crucial in preventing negative media influences. The research preceding this paper shows that students whose parents do not control media content spend more time with the media, thus confirming the hypothesis (H2) that there is a correlation between time spent using new media and parental control. In cases where parents do not understand the use of their child's media content, it is possible for children to adopt undesirable behaviors. Today, the media is an extremely important socializing agent, and a particular danger can be caused by the inability to identify inadequate and manipulative content in the media. According to the study by Bickham and Rich (2006: 388) on the impact of exposure and television viewing on social isolation, children who watch television with peers, regardless of time spent, are found to be engaged in more social interactions with peers in the social environment. The American Academy of Pediatrics (2009) also proposes parents' involvement to spend time with their children while using media, and comment on the content of media with children to avoid negative media influences.

Learning non-verbal communication is only possible through face-to-face interaction, through which social skills that are crucial in adulthood (Bosacki, Astington, 1999: 242). The results of the study show that the assessments between parents and teachers in the field of students' social skills are almost identical, thus confirming the hypothesis (H3) that there is no difference in the perception of the adoption of social skills between teachers and parents.

\section{Conclusion}

The impact of new media on the development of social skills in children is inevitable. The organization of children's free time spent with their peers is increasingly being replaced by the use of 
media and technology. Consequently, for the quality media use, it is extremely important parents and teachers to assist and control the content that children use and to be actively involved in spending time with children and new media. It can be stated that the media is a potentially important socializing agent, but that their influence depends on a number of factors, such as: media selection, time of use, content selection, conditions of use and subgroup characteristics. The students with autism spectrum disorders, included in this study, dominantly exhibit discrepancies in the field of communication and social skills, so this research shows that special attention should be paid precisely to the use of media and to involve children with different types of disabilities in the future research.

Since parents and teachers are equally well acquainted with students' social skills, fostering their development of is one of the basic tasks of parents as well as contemporary educational institutions. In developing future curricula, the media aspect, especially the development of media literacy, needs to be closely addressed. Observing today's children, it is indisputable that they spend more and more time using new media, and it would be relevant, given the impact of these media on their social skills, to consider whether new media also affect the dimension of their emotional development.

\section{References}

Alexander, A., Hanson, J. (2003). Taking sides-mass media and society, McGrawHill/Dushkin, Connecticut

American Academy of Pediatrics (2009). Council on Communications and Media. Policy Statement-Media Violence. Pediatrics, 124, 1495-1503

Bickham D. S., Rich M. (2006). Is television viewing associated with social isolation? Roles of exposure time, viewing context, and violent content. // Arch Pediatr Adolesc Med 160, Apr, 4, 387-392

Bosacki, S., Astington, J. W. (1999). Theory of mind in preadolescence: Relations between social understanding and social competence. // Social Development 8, 237-255

Hoza, B. (2007). Peer functioning in children with ADHD. // Journal of Pediatric Psychology 32, 6, 655-663

Ilišin, V. (2003). Media for Leisure Time of Children and Youth, Media Research 2, 9-34

Ilišin, V., Bobinac Marinović, A., Radin, F.(2001). Children and the Media: The Role of The Media in Everyday Life of Children. DZOMM/IDIZ

Katz, L. G., McClellan, D. E. (1999). Encouraging the Development of Children's Social Competence, Zagreb, Educa

Klarin, M. (2006). The Development of children in a Social Context. Jastrebarsko: Naklada Slap

Lievrouw, L. A. and Livingstone, S. (2006). (eds.), Handbook of new media: social shaping and social consequences-fully revised student edition. London, UK : SAGE Publications, 1-14

Lister, M., Dovey, J., Giddings, S., Grant, I. and Kelly, K. (2009). New Media: a critical introduction. Routledge 270 Madison Ave, New York, NY 10016

Livazović, G. (2009). Theoretical and Methodological Features of Media Influence on Adolescents. // Life and School 21, 108-115

Manovich, L. (2002). New Media from Borges to HTML. The New Media Reader, edited by Noah Wardrip-Fruin and Nick Montforl, The MIT Press

Miljković, D., Rijavec, M. (2002). Better be the Wind than a Leaf. Zagreb: IEP.

Raboteg-Šarić, Z. (1997). Socialization od Childern and Youth. // Društvena istraživanja: časopis za opća društvena pitanja 6, 4-5, 30-31

Rajić, A. (2011.). Social skills. Obiteljski centar Primorsko-goranske županije, Rijeka. http://ocpgz.hr/clanci_socijalne_vjestine.html (Accessed 21.10.2019.)

Rožić, I. The Influence of the Media on the Value System of Young People in Split and Padua. http://elib.efst.hr/2012/2102773.pdf (4.7.2019)

Valkenburg, P. M., Taylor Piotrowski, J. (2017) Plugged // How Media Attract and Affect Youth. New Haven: Yale University Press

Zgrabljić Rotar, N. (2005). The Media-Media Literacy, Media Content and Media influence; Media Literacy and Civil Society, Sarajevo, Media Centar 